\title{
Pilgrimage to Holy Sites Cultural Heritage and Religious Tourism from Jesus Baptism Site-Jordan River to Ain Saleem
}

\author{
Mohammed Waheeb, Abdull Aziz Mahmoud \& Dima Krishnan \\ The Hashemite University (HU) \\ Jordan
}

\begin{abstract}
Important events regarding the early beginnings of Christianity took place in the holy land near Jordan River, where most of people believe that Jesus was baptized in the traditional baptizing site. However, the early Christian pilgrims, who followed the traditions and reached significant sites such as Aenon or Ain near Saleem during their pilgrimage and documentation missions, presented us with detailed explanations regarding the religious sites related to the baptism of Jesus. These explanations coincide with the results of the recent archaeological excavations and with the holy verses as well.
\end{abstract}

Keywords: Byzantine Age, Religious Tourism, Cultural Heritage,, Jordan River, Pilgrimage Routes, Bethany beyond Jordan.

\section{1-Introduction:}

At the dawn of Christianity and shortly after the Christ's birth in Bethlehem, John the Baptist, who was a priest at the time, started preparing for the arrival of the Christ whilst roaming villages and cities on the eastern bank of Jordan River (Matthew 3:4) .

Excavations started in 1996 supported the assumption that John the Baptist dwelt in the village of Bethany Beyond the Jordan, which is located to the eastside of Jordan River in the wilderness. Near this village there is a valley called Wadi al-Kharrar that is less than $2 \mathrm{~km}$ away from Jordan River (Waheeb1997, 1998, 1999, 2000, 2001).

Considering the importance of such sites it was a priority to protect them from further destruction, caused by the effect of erosion especially that the area is made of brittle sandstone.

\section{2-Survey and excavations}

Field survey and excavations aimed to answer questions such as: where did the baptizing of the Christ and John the Baptist took place? Where were the stations located along the pilgrim road? And weather this road was the same road taken by the Christ, when he arrived at the area and left it? (Avi-Yonah, 1950, 1954).

But perhaps the question which answers all the enigmatic questions should be as follow: Where is the spot from which Christianity was spread into the world?

The discovery of the real site of baptism gave rise to many questions, because the general idea was that Jesus was baptized in Jordan River, whereas archeological findings indicate that it was to the east of Jordan River. Thus, it is only fair to consider the site supported by scientific evidence and proof as the true site of baptism i.e.: the site east of Jordan River.

The site facing Jericho was merely chosen as a traditional site due to its closeness to Jerusaleem.This fact is strongly supported by holy verses, which mention that the Baptism took place in Jordan. ${ }^{2}$

\footnotetext{
${ }^{1}$ The survey \& excavations team had to overcome natural and human difficulties during the work in Jordan valley from 1996 till 2002, while documentation phase of the site \& surrounding area extended to 2020.

2 "Then cometh Jesus from Galilee to the Jordan unto John, to be baptized of him" (Matthew 13:3) also we can see another verse: "And it came to pass in those days that Jesus came from Nazareth of Galilee, and was baptized of John in the Jordan." (Mark 1:9) Where the last verse in Luke shows: "Now it came to pass, when all the people were baptized, that Jesus also having been baptized, and praying. The heaven was opened" (Luke 3:21) Furthermore we can track another verse says:

"These things were done in Bethany beyond the Jordan, where John was baptizing" (John 1:28), "And he went away again beyond Jordan into the place where John was at the first baptizing; and there he abode" (John 10:40). Consequently, these verses verify that Jesus headed to this location.
} 
The arrival of the Christ at Bethany was witnessed by many evidences. That is clear in the verse that says that John's followers came to him inquiring (John 3:26). This proves beyond the shadow of doubt that the baptism site is to the east of Jordan River (see Abel, 1932)

\section{3-Early pilgrims}

Then the convoys of early pilgrims came to Wadi al-Kharrar,(Harding:UD) which is in the center of Bethany. Where the prophet Elijah was rasping the arrival of Jesus. In the other hand pilgrims and believers also arrived at the place where the Lord was baptized to visit it, get the blessings, and sometimes to even dwell close to it, see fig: 1 (Conder, 1882).

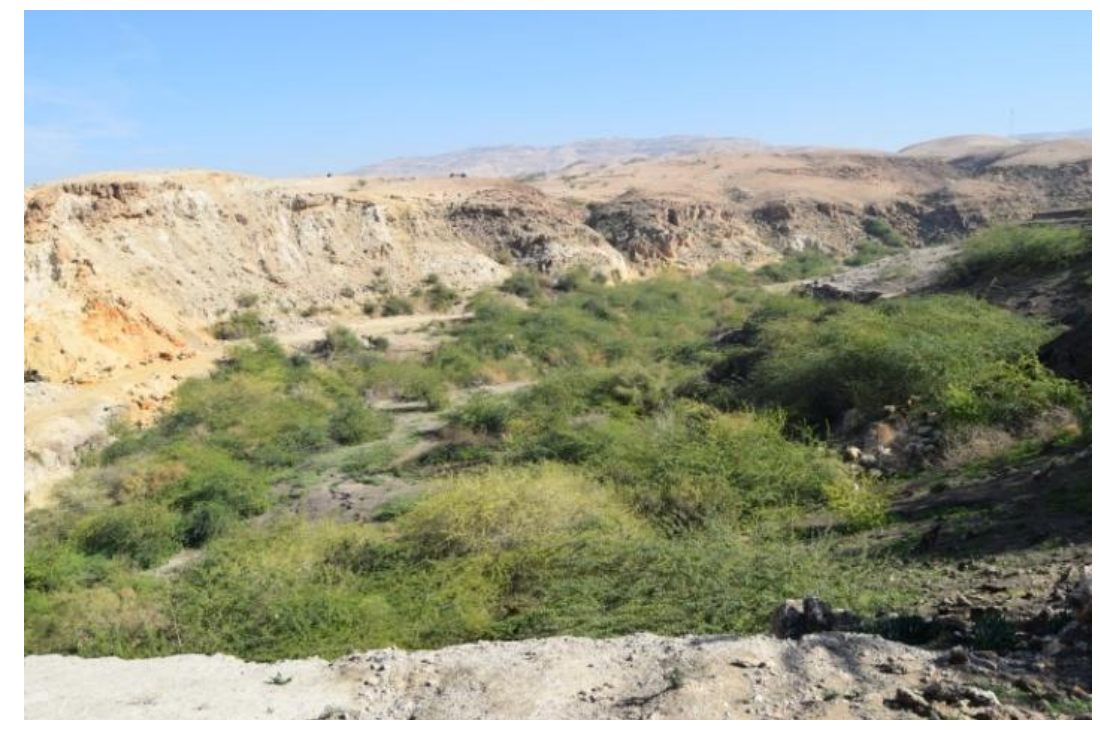

Fig.1: General view of 'AinSaleem close to WadiHesban(Waheeb:2020)

Some of the pilgrims and travelers described the place elaborately. For example, Pilgrim of Bordeaux, who visited the area in $333 \mathrm{AD}$, said that the baptism site is close to Wadi al-Kharrar, where modern excavations are conducted in the meantime (Waheeb: 1999), The traveler (Theodosius) who visited the site in $530 \mathrm{AD}$ emphasized on the fact that the baptism site lies to the east of Jordan River, and that the Byzantine Emperor (Anastasius) built John The Baptist's Church on the spot where the lord was baptized. Further he remarked that the church was built on arches and vaults to protect it from the flood of Jordan River in the winter (Bordeaux Pilgrim: 333).

(Arculf), Saint (Willibalad), and the Russian Traveler (Abbot Danial) emphasize that the Christ was baptized in the east bank, where a church was built on the edge of the River to commemorate the event(PPTS1887,1888,1889,1893).

Thus, it is clear that the baptism took place in Wadi al-Kharrar,on the eastern bank, and that John's church represents a crossing point to the sacred place where the first believers were baptized. The travelers' testimonies confirm that this Wadi is where John was first baptizing, and is where Jesus was baptized as well.

The results of archeological survey were consistent with the travelers' description. The foundations of the church were soon found, with its arches and vaults designed to protect the church from the seasonal flood of the River (Waheeb, 1998)

Bethany is the sole places were churches were built continuously regardless of the fact that floods may destroy them. In addition, the monks who dwelt the area carved their caves in sandstone; these small caves became places for prayers, where the monks relived the lives of the first believers. We should not disregard what the travelers say about the existence of Elija's and John's caves, in the spot where many Saints and prophets have passed (Wilkinson: 1981).

The pilgrims then gradually ascend to the southern bank of the Holy Valley (Wadi al-Kharrar) alongside the murmuring of the spring that gave it its name, and under the shades of palm trees, tamarisk, reeds, and thick vegetation that covers the entire valley. They rest next to a large pool designed to collect water from Wadi alKharrar through a channel. 


\section{4-The Excavations}

\section{4-1.large pool}

It is clear that the pilgrims rested near this pool since a small building, built on a plan facing Wadi al-Kharrar and Jordan River, was discovered. This building represents and includes a church that was built for the sake of the pilgrims.

The discovery of the pool is quite impressive, since it's the only pool that is fed by John's spring; the pool was built to facilitate mass baptizing once the pilgrims enter the Holy Valley, and before they head to the church for prayers. Soon afterward, they continue their pilgrimage to John's church, and on their way they encounter a small structure built by a monk for the purpose of prayers and abstinence in this holy spot. The pilgrims reach the church of Elijah, where one stands and contemplates the remains of buildings that are spread all over the area. The verse "Where John was first baptizing"; echoes into one's mind, for the active spring still beats down the hill, and the resonance of its murmurs is still heard in the wilderness.

This valley is of peerless beauty between the Jordan Valley, where it suddenly descends without reaching the eastern meadows, and runs westwards till it reaches Jordan River, in which the water breathes life into it.

\section{4-2.Tell Mar Elyas (Kharrar)}

The first building that the pilgrim sees is the small sized church, which gives us an idea about the roof that was raised on vaults, the mosaic floor ornamented with cross shapes, and the court yard that faces north and contains the largest water tank. The roof of the structure was shaped into half a cylinder, and the upper surface was leveled and paved with white mosaic.

To the east of this church, the pilgrim can see a small building that must have been built for religious purposes. Remains of the water system where found next to the northern edge of this building. Ceramic pipes were used to draw sweet water from the Gharabeh valley, which is 2 kilometers away. Precipitation tanks used to clarify the waters were found as well, along with a large well/tank seven meters deep.

Channels were spread into the Kharrar to feed the pools and tanks there. In addition to that one can view that the Tell is surrounded by a protective wall to preserve the structures that are built on its slopes.

A medium sized church was discovered on the northern side of the wall, another on the western side and the remains of a mosaic floor were discovered on the northwestern side. All this shows the immense effort given to build these structures (Piccirillo, 1996)

\section{4-3. Water System}

A washing and baptizing pool was constructed on the southern edge, and two on the northern edge, and the remains of the channel can still be seen among the remains of the rooms constructed by Orthodox monks in the beginning of the twelfth century.

One may wonder why where these buildings constructed on this small low hill on the edge of a valley, subjected to the harsh elements of nature. The only logical answer is that emperors and monks competed to build religious buildings on the site due to its holiness.

By these acts, they only aimed to please God. For example, the name of the priest (Roterrious), who was the head of Wadi al-Kharrar's monastery, was found in the inscriptions found on the Tell.

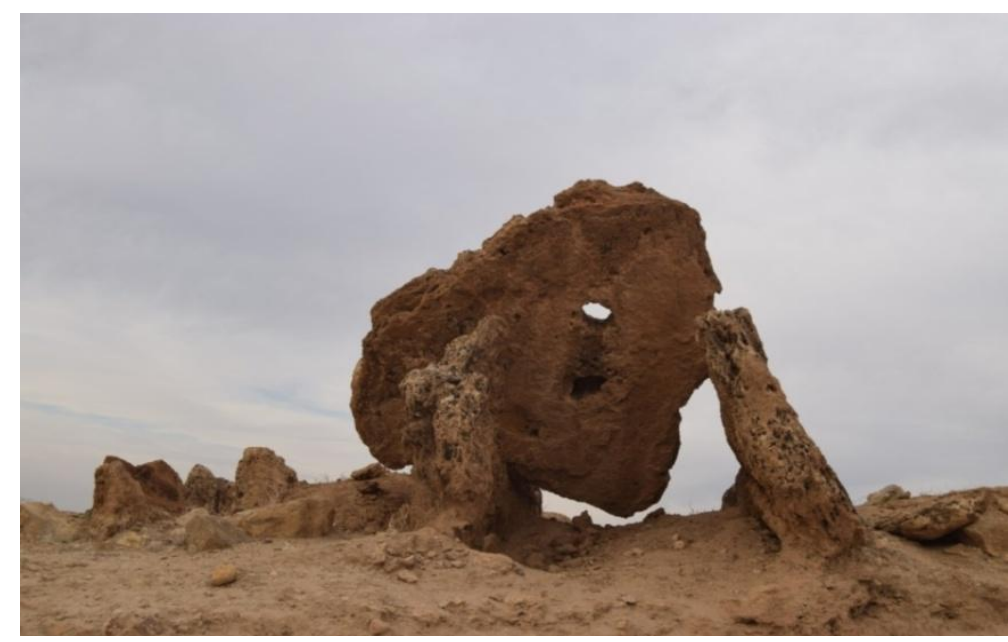

Fig.2: Few dolmens still existed in the area near 'Ain Saleem ( Waheeb, 2020) 
We are by no means to describe the spring in Wadi al-Kharrar. There is no doubt that the Kharrar spring was called "John the Baptist's spring". This is undoubtedly where John was first baptizing.

The pilgrims then continue their journey walking along the side of the ceramic pipes channels, which were constructed to supply the pilgrims with water in the first place. A walk of two kilometers will bring the pilgrims to the Gharabeh Valley, where large pools and rest houses were constructed, some of these where excavated (Fig.2)

\section{5- Holy places}

\section{5-1.Livias}

At that point the pilgrims proceed to Rama, where a hill called Tell al-Rama still standing nowadays. Rama is famous historical site for its remains and buildings. This Tell is one of the stations on the pilgrimage road. It has been partly excavated during 2002, a mosaic floors with architectural remains were found and dated to Roman, Byzantine and Islamic Age, (Waheeb: 2002). The remains probably includes the floors of churches (see Piccirillo, 1987)

No wonder that the place is used as a cemetery nowadays since it has been regarded as a sacred and holy place for hundreds of years now.

\section{5-2.AinSaleem}

The most visible site in this area is Tell 'Ain Saleem, which stands immediately south of lower part of Wadi Hesban, close to the highway on the stretch of land leading westward to the Dead Sea shoreline. At the point where Wadi Hesban enters the floor of the valley, the area was been a military zone till 2002, after signing peace treaty, the area subjected to extensive survey and excavation (Ibach, 1987)(Fig. 3)

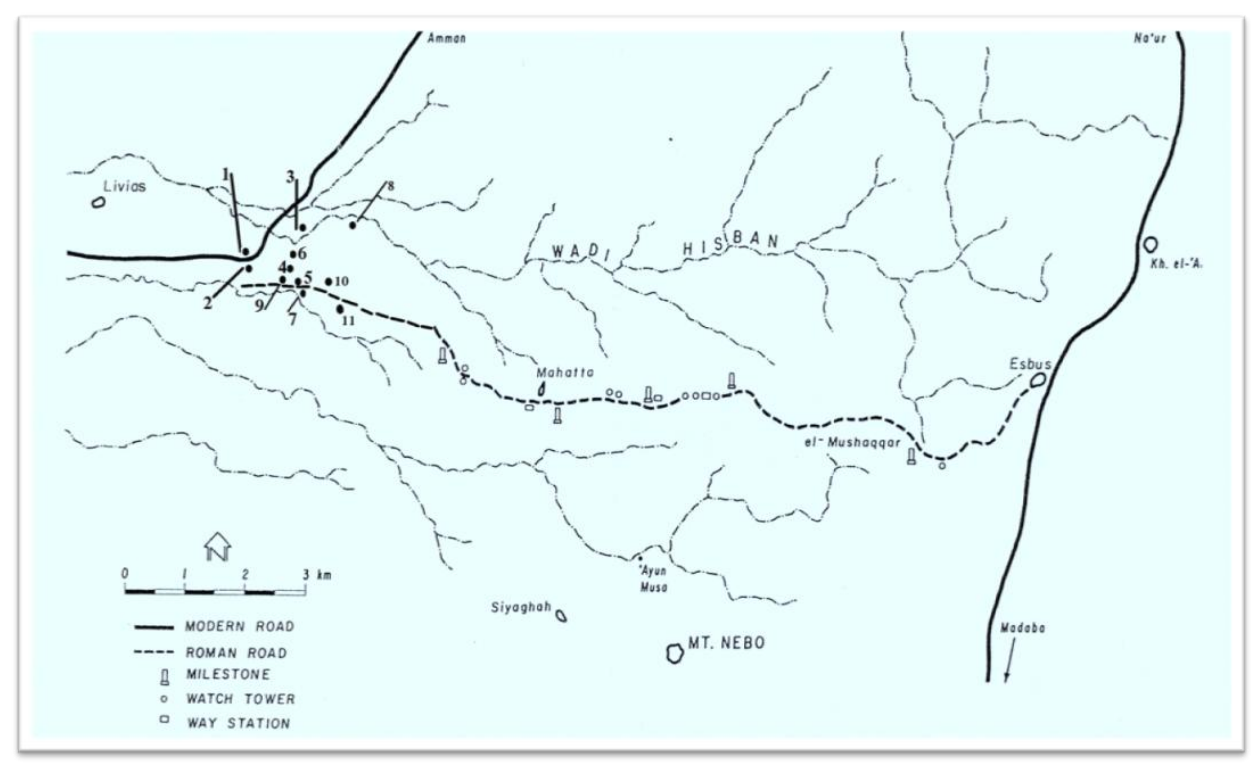

Fig. 3: A map showing 'Ain Saleem and the surrounding zone: 1.Tell Iktano,2.Tell el-Husan,3.Dolmen field,4.Tell 'Ain Saleem,5. 'Ain Saleem, 6. 'Ain Saleem (fawara), 7.Watch tower,8.Walls and canals,9.Caves,10. Watch tower (1), 11. Watch tower (2).

Excavations were concentrated in the Tell (site No.4) and the watchtowers Nos. 7, 10, and 11. The results reveal the presence of Iron Age II period remains, a large settlement appeared and reused during the Roman and Byzantine Periods. These discovered buildings were located between 'Ain Saleem and 'Ain Saleem al-Fawara, just on the northern edge of Roman Esbus-Jericho Road.(Avi-Yonah:1954) see also (Waterhouse, \&. Ibach,. 1975)

The Iron Age remains occupies the acropolis area of the Tell which consist of square and rectangular shape rooms, built of undressed limestone blocks, while the Roman and Byzantine remains occupied an area approximately 4 acre (village site). Several water channels were found in the surrounding plains which drains the water of the springs to several gardens, agricultural fields, and locations here and there near the Roman Road, in addition to that architectural remains occupied the flat area on the eastern and northern slopes of the Tell between the above mentioned two springs.

Depending on the recovered artifacts and way of construction, the channels and water installations are dated back to early Roman Period and continued to be used up to late Byzantine era. 
The excavations in the adjacent sites of 7, 10, 11 (fig. 3) yield quantities of Roman Period pottery sherds mixed with strong late Byzantine sherds. The discovered small sites located on both alignment of the rout were served as a watchtowers to control the Roman Road and safeguard the pilgrims caravan, and has close connection with Tell Saleem which might be used as a pilgrims station during the Byzantine periods In addition to that, we should take into consideration the well-known site Mahatat Al-Hujjaj (Pilgrims Station) which is still existed till nowadays, situated on the top of high mountain close to Mount Nebo and Moses springs, just $3 \mathrm{~km}$ to the east of this location (Fig:4)( Saller. and Bagatti: 1949)

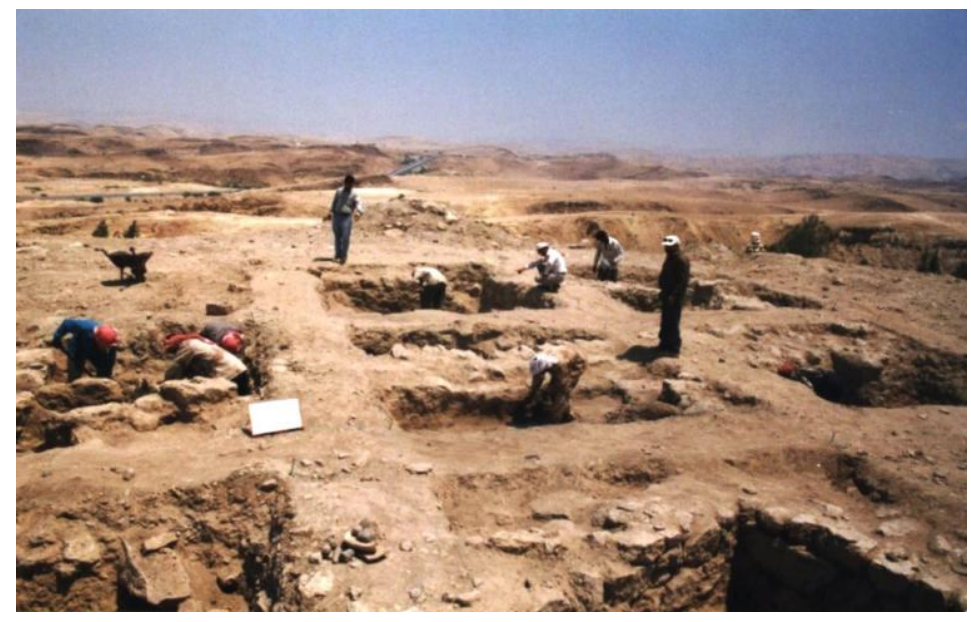

Fig.4: Excavations in“Ain Saleem near WadiHesban(Dajeh :2015)

The question arise here after assessing the recent discoveries, dose the place of "Ain Saleem and the nearby Livias plain fulfill the requirements of John 3: 23 and of tradition?

The whole area, included the Tell which is overlooking Livias plain, is well watered, and the description of Antonious bring us in fact to springs lying some $6-7 \mathrm{~km}$ east of site of Jesus Baptism(Bethany Beyond the Jordan)(Fig. 5,6).

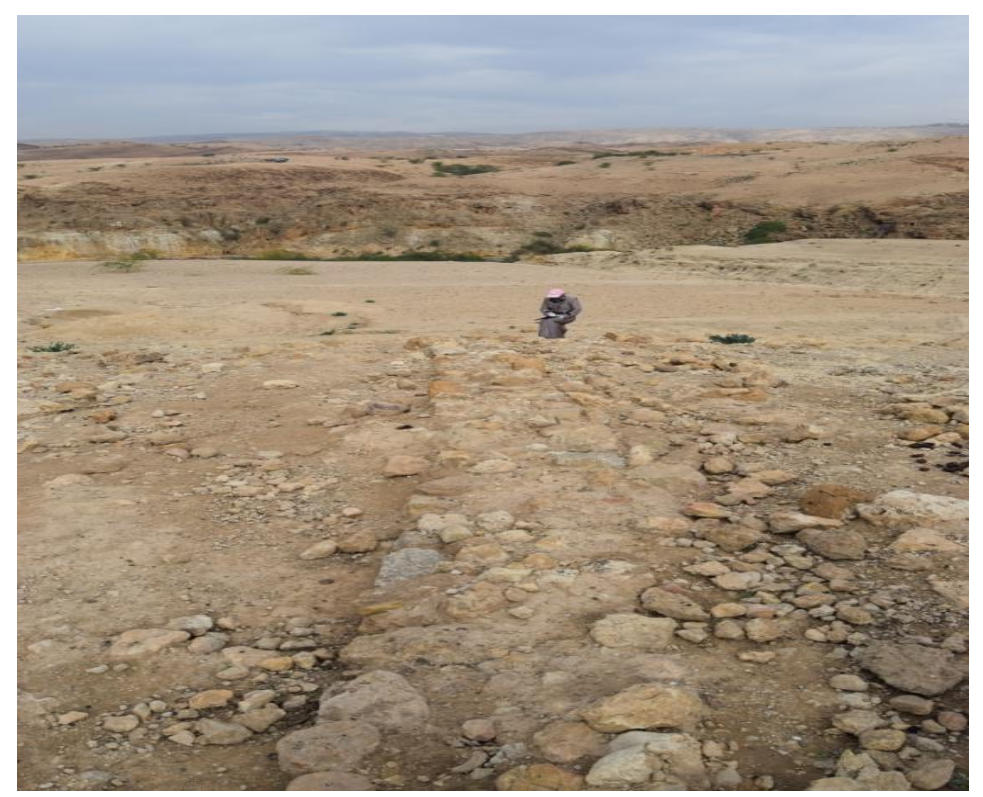

Fig. 5: Walls used to be part of the water system in 'Ain Saleem(waheeb2019) 


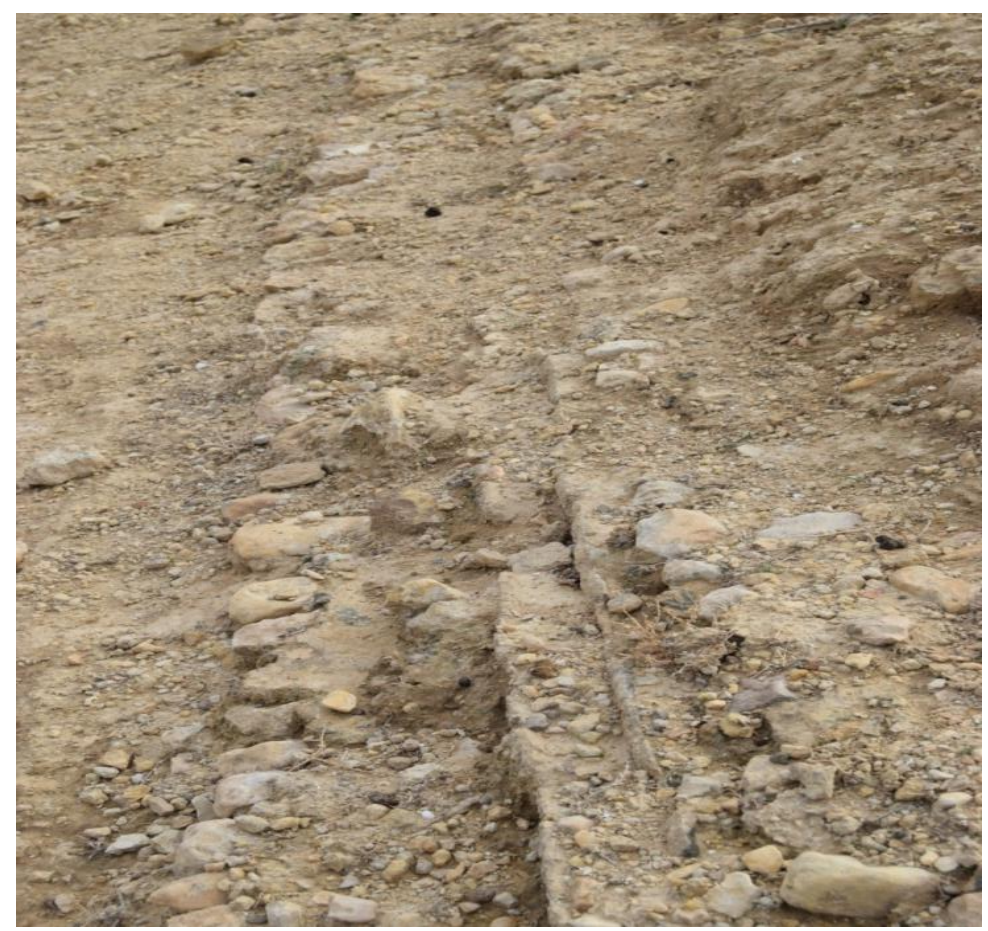

Fig.6: Water channels still visible on the surface of 'Ain Saleem(waheeb2019)

\section{Conclusion}

The pilgrims pursue their Journey to Madaba and head to Mount Nebo, ascending steep slopes and crossing rocky roads, which are the characteristics of the topography of the area, until they reach their destination, which is either the top of Mount Nebo or Hesban . This represents the end of their pilgrimage.

They stand there and look upon the routes in the valleys and 'Ain Saleem, they have crossed on their way to this historic place. 'in Saleem where john had last worked, could have a living memory until it was recorded in literature, so this sequestered spring with its surrounding zone, has an historical claim along with its core site Bethany Beyond Jordan to rank as a well-established site in the history of religions. (Hirschfeld, 1992)

Beneath the green leaves provides in idyllic and yet appropriate setting close to the Roman road for John's Baptisms. Several other springs rise in the vicinity, so that the name Aenon, which is in the plural also fit.

The place is close to Mount Nebo and Moses springs, while Mukawer is no so far from this location where John was beheaded according to the gospels.

The recovered Iron Age II materials and architecture in Tell 'Ain Saleem, gives clear indication and strong connection with nearby hills in the same area such as Tell Habasah and Matabba, where pray identifies the same date in the region.

According to Antonious "On that side of Jordan is the fountain, where John used to baptized, from it to the Jordan is two miles. In the valley itself Heilas was found, when the raven used to bring him bread and meat. On the side of the valley live a multitude of hermits".

Antonious among the earlier pilgrims, mentions the spot, and in placing it opposite Jericho, he is more in accordance with Josephus, who says that Elijah travelled towards the south, (Antonious: 40). The name of Salamida is mentioned only by him, but later it was changed to Ain Saleem and Livias.

\section{Bibliography:}

The New Testament.

Abel, R. (1932) Exploration Du Sud-Est de la Vallee du.

Avi-Yonah, M. 1950-51, the Development of the Roman Road System in Palestine. Israel Exploration Journal 1:54-60.

Avi-Yonah, M 1954, The Madaba Mosaic Map with Introduction and Commentary, Jerusaleem.

Conder. R, 1982, Survey of Eastern Palestine. London.

Ibach, R.D. 1987, Archaeological Survey of the Hesban region: catalogue of sites and characterization of periods.

Hesban 5. Berrien, Springs, M1: Institute of Archaeology/ Andrews University.

Fingan, B., 1969 Archaeology of the new testament, New Jersey. 
Johannes Phocas: Pilgrimage in the Holy Land 1185 AD, PPTS 1889.

Harding, L. (Un-dated) Bassat al - Kharrar, Unpublished report, Registration center of Department of Antiquities of Jordan, B, g, Amman.

Hirschfeld, (1992) The Judean Desert Monasteries in the Byzantine period. Yale University, U.S.A.

Piccirillo, M. 1987, The Jerusaleem-Esbus Road and its sanctuaries in Trans Jordan pp. 165-172 Studies in the History and Archaeology of Jordan 3, fed. A. Hadidi. Amman: Department of Antiquities. 11-1989 Herr, L.G. The pottery finds pp. 299-354 in Madaba Plains Project 1: the 1984 season at Tel el-'Umeiri and Vicinity and Subsequent Studies, EDS. L.T. Geraty, L.G. Herr, Q.S. Labianca, and R.W. Younker. Berrien Springs, M1: Andrews University/Institute of Archaeology.

Piccirillo, M. 1996, La Strada Romania Esbus - Livias, LB, 46, pp. 285-300.

Saller, S.J. and Bagatti, B. 1949, The Town of Nebo (Khirbet el-Mekhayyat). Studium 7. Jerusaleem: Franciscan. PPTS, 1887 The Bordeaux Pilgrim 333 AD.

PPTS, 1889 The Pilgrimage of the Holy Paula by St. Jermo 382 AD.

PPTS, 1893 Theodosius on the Topography of the Holy Land 530 AD..

PPTS, 1886 The Building of Justinian by Porcopius 560 AD.

PPTS, 18881875 The Pilgrimage of Arculf 670 AD..

PPTS, the Pilgrimage of the Abbot Daniel 1106-1107 AD.

Waheeb, M. 1998, Wadi al-Karrar Archaeological Project (Al-Maghtas). ADAJ XL11: 635-638.

Waheeb, M. (1997). Report on the Excavations at Wadi al-Kafrein Southern Ghor (Al Aghwar). ADAJ, 41, 463468.

Waheeb, M. 1998, Wadi al-KharrarAl-Maghtas. AJA 102, 3,601.

Waheeb, M. (1998). New discoveries near the baptism site, Occident and Orient, 3(1), 19-20.

Waheeb, M. (1998). Wadi al-Kharrar al-Maghtas, AJA, 102(3), 601.

Waheeb, M. (1998). Wadi al-Kharrar Archaeological Project, ADAJ, 43, 635-638.

Waheeb, M. (1998). Wadi al-Kharrar, AJA, 102(3), 106.

Waheeb, M. (1999). Wadi al-Kharrar Archaeological Project. The Monastery, ADAJ, XLIII, 549-557.

Waheeb, M. (2001). Archaeological Excavations at the Baptism site Bethany Beyond the Jordan. Bible andSpade, 14(2), 43-53.

Waheeb, M. (2001). Wadi al-Kharrar Archaeological Project. The Survey Studies in the History and Archaeologyof Jordan, VII, 591-601.

Waheeb,M,2002, Excavation in Tell Rama ,Jordan Valley , unpublished report ,DAJ Reports ,Jordan.

Waterhouse, D. Ibach, R. 1975, Roman Road from Livias to Esbus, in Seminary Studies, 13, No. 2, 217-233.

Wilkinson, J. 1981, Egerias Travels to the Holy Land. Jerusalem. 